\title{
Chitosan and phenolic compounds in the control of anthracnose in mango
}

\author{
Luana Sabrine Silva ${ }^{1}$, Edson Hiydu Mizobutsi ${ }^{2}$, Regina Cássia Ferreira Ribeiro ${ }^{2}$, \\ Fernando da Silva Rocha ${ }^{3}$, Gisele Polete Mizobutsi ${ }^{2}$, Sabrina Gonçalves Vieira de Castro ${ }^{4}$
}

\begin{abstract}
Mango (Mangifera indica L.) has great socioeconomic importance to Brazil, but its production is affected by anthracnose. Chitosan films have shown potential in controlling this disease. In this study, the effect of the association of chitosan with phenolic compounds and extracts on the Colletotrichum tropicale development was evaluated. Phenolic compounds and extracts from mango peel were incorporated into $2.0 \%$ chitosan solutions and tested in vitro. In the in vivo experiment, after pathogen inoculation and application of treatments, fruits were evaluated for anthracnose incidence and severity. Controls consisted of the application of water or pure culture medium and fungicide imazalil. The experimental design was completely randomized and data were submitted to analysis of variance. In the in vitro test and in the assessment of disease intensity, means were compared using the Scott-Knott and Tukey tests $(\mathrm{p}<0.05)$, respectively. Controls were compared to the other treatments using the Dunnett test $(p<0.05)$. Total growth inhibition, conidia production and $C$. tropicale germination were verified with the incorporation of citric, pyrocatecoic and transcinamic acids to chitosan, with no significant difference between them and the fungicide. Low anthracnose incidence and severity was observed in mangoes treated with chitosan combined with phenolic compounds.
\end{abstract}

Index Terms: Alternative control, Colletotrichum tropicale, phenols, plant extracts, post-harvest diseases.

\section{Quitosana e compostos fenólicos no controle da antracnose da manga}

Corresponding author: luanasabrine.92@gmail.com

Received: June 07, 2021

Accepted: September 13, 2021

Copyright: All the contents of this journal, except where otherwise noted, is licensed under a Creative Commons Attribution License.

\section{$(\mathrm{cc}) \mathbf{E Y}$}

Resumo - A manga (Mangifera indica L.) tem grande importância socioeconômica no Brasil, porém sua produção é afetada pela antracnose. Filmes de quitosana têm demonstrado potencial no controle desta doença. Neste estudo, avaliou-se a associação de quitosana com compostos fenólicos e extratos no desenvolvimento de Colletotrichum tropicale. Compostos fenólicos e extratos da casca da manga foram incorporados às soluções de quitosana a $2,0 \%$ e testados in vitro. No experimento in vivo, após a inoculação do patógeno e aplicação dos tratamentos, os frutos foram avaliados quanto à incidência e severidade da antracnose. As testemunhas consistiram na aplicação de água ou meio de cultura puro e do fungicida imazalil $\left(2,0 \mathrm{~mL} \cdot \mathrm{L}^{-1}\right)$. O delineamento experimental foi inteiramente casualizado e os dados foram submetidos à análise de variância. No teste in vitro e na avaliação da intensidade de doença, as médias foram comparadas pelos testes de Scott-Knott e Tukey ( $\mathrm{p}<0,05)$, respectivamente. As testemunhas foram comparadas aos demais tratamentos pelo teste de Dunnett $(\mathrm{p}<0,05)$. Inibição total do crescimento, produção de conídios e germinação de $C$. tropicale foi verificada com incorporação à quitosana dos ácidos cítrico, pirocatecoico e transcinâmico, não havendo diferença significativa entre eles e o fungicida. Foi verificada baixa incidência e severidade de antracnose nas mangas tratadas com quitosana combinada com compostos fenólicos.

Termos para indexação: Controle alternativo, Colletotrichum tropicale, fenóis, extratos vegetais, doenças pós-colheita.

\footnotetext{
${ }^{1}$ M.Sc. in Plant Production, State University of Montes Claros/Department of Agricultural Sciences, Janaúba-MG. Brazil. Email: luanasabrine.92@

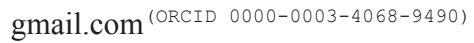

${ }^{2} \mathrm{PhD}$, Professor, State University of Montes Claros/Department of Agricultural Sciences, Janaúba-MG. Brazil. Email: edson.mizobutsi@

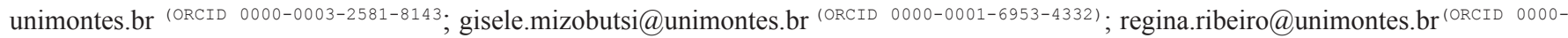
0001-5138-8402)

${ }^{3} \mathrm{PhD}$, Professor, Federal University of Minas Gerais, Montes Claros-MG. Brazil. Email: rochafs@ufmg.br (ORCID 0000-0002-2506-3441)

${ }^{4}$ Agronomy undergraduate student, State University of Montes Claros/Department of Agricultural Sciences, Janaúba-MG. Brazil. Email: sahgvieira18@gmail.com ${ }^{\text {(ORCID 0000-0002-3909-6703) }}$
} 


\section{Introduction}

Mango (Mangifera indica) stands out in the world fruit market for being one of the most consumed fruits and with high acceptance among consumers. Mango cultivar 'Palmer' has been gaining prominence in the market for its quality characteristics such as: lower amount of fiber, larger fruits, higher soluble solids content, very red hue when ripe and yellowish pulp (MOUCO, 2010). In addition, the bioactive compounds present in mango such as ascorbic acid, $\beta$-carotene and polyphenols contribute to its antioxidant and nutritional properties (NTSOANE et al., 2019).

In economic terms, mango is of great importance to Brazil, since the country is among the largest producers and exporters in the world. However, anthracnose, the main post-harvest disease, limits the expansion of mango to new markets. The appearance of dark spots on infected fruits provides undesirable and unfeasible appearance for consumption and exports (BATISTA et al., 2016). Mango anthracnose in Brazil was believed to be exclusively caused by Colletotrichum gloeosporiodes (Penz.) Penz. $\&$ Sacc, however, recent phylogenetic studies have shown that five other species of the genus Colletotrichum are associated with this disease (LIMA et al., 2013; 2015), which makes the implementation of more efficient control measures essential.

The development of anthracnose in mango has been controlled through chemical treatment, with the use of synthetic fungicides, hydrothermal treatment or the combination of both (AGROFIT, 2019). However, the inappropriate use of fungicides has induced the emergence of resistant isolates (ZHENG et al., 2013), being a threat to public health and environment. Hydrothermal treatment, in turn, induces the early ripening of fruits, increased weight loss, color change, reduced firmness and accelerated or blocked ripening (BRITO et al., 2009).

Alternative control based on less polluting and safer strategies is of great interest for mango producing regions due to the demand of the consumer market for high quality fruits and concern with excessive use of pesticides (NEGREIROS et al., 2013). Several coatings and films have attracted attention in recent years (GALUS; KADZINSKA, 2015). The use of chitosan has achieved excellent results in the control of phytopathogens (OLIVEIRA et al., 2018) and in fruit conservation (BAUTISTA-BÃNOS et al., 2016; ESHETU et al., 2019).

Chitosan is a natural heteropolymer extracted from the crustacean exoskeleton, with many functions (CHOI et al., 2016; HAMED et al., 2016). As agricultural tool, results have shown that chitosan can control many pre- and post-harvest diseases (MALERBA; CERANA, 2016) by inducing numerous biological responses, which include: lignification, variation in ion flow, interaction with plasmatic membrane components, chitinase activation, phytoalexin biosynthesis and expression of genes related to defense mechanisms (EL HADRAMI et al., 2010). Despite the various benefits resulting from its use in fruits, chitosan application can be limited by its fragility and low antioxidant capacity (SIRIPATRAWAN; VITCHAYAKITTI, 2016). The cationic properties of chitosan allow it to establish electrostatic interactions with other compounds (RUBILAR et al., 2013). Essential oils, plant extracts, antimicrobial agents and phenolic compounds can be added to chitosan formulations to improve its physical, mechanical and biological characteristics (SANTOS et al., 2012; ALOUI et al., 2014; VAN DEN BROEK et al., 2015; ATARÉS; CHIRALT, 2016).

Phenolic compounds are the secondary metabolites most abundant in the plant kingdom and in fruits, they act as natural antagonists of pathogens (ADIKARAM et al., 2015) and potent antioxidants (AJILA et al., 2007; KIM et al., 2010; AGATONOVIC-KUSTRIN et al., 2018). In recent years, different phenolic compounds have been incorporated into chitosan films (ALJAWISH et al., 2016; WU et al., 2016; LIU et al., 2017), but there are few reports on the effect of these two associated substances on the control of post-harvest mango diseases. In this sense, the aim of this work was to evaluate the effect of the association of chitosan with phenolic compounds and extracts on the development of anthracnose in mango caused by Colletotrichum tropicale.

\section{Materials and methods}

\section{Colletotrichum tropicale isolate}

Colletotrichum tropicale isolate was obtained from fruits with characteristic anthracnose symptoms collected in areas of commercial cultivation in the municipality of Janaúba-MG. The fungus identification was confirmed from the analysis of the partial sequences of genes APN2MAT1-2; APN2 and GAPDH-IGS at the Laboratory of Mycology - Federal Rural University of Pernambuco.

\section{Obtaining fruits}

'Palmer' mangoes were manually harvested in two different physiological maturation stages: 2 cream pulp color and yellow pulp color for the preparation of extracts and evaluation of the anthracnose intensity, respectively. Subsequently, fruits were washed with water and mild soap and left at room temperature to dry.

\section{Formulation of mango peel extracts and phenolic compounds}

For the preparation of extracts, fruit peels were separated from pulps, with cuts varying from 2 to $3 \mathrm{~mm}$ in thickness and taken to dry in an oven with forced air circulation under temperature of $40^{\circ} \mathrm{C}$ for $72 \mathrm{~h}$ and then 
ground. Extraction was carried out in Soxhlet system using three types of solvent: hexane, ethyl acetate and methanol, according to methodology proposed by Silva et al. (2019). Subsequently, a stock solution for each extract was prepared at concentration of $5 \mathrm{mg} \cdot \mathrm{mL}^{-1}$ using sterile distilled water and $1 \%(\mathrm{v} / \mathrm{v})$ hydrophilic non-ionic surfactant Tween 80 (polyoxyethylene sorbitan monoleate) as diluent. Each stock solution from extracts was incorporated into chitosan.

Phenolic compounds citric acid, pyrocatecoic acid, transcinamic acid, gallic acid, caffeic acid, methyl gallate, quercetin and resorcinol were chosen for this study based on a bibliographic survey of the antifungal action of these substances against phytopathogens and their presence in the chemical composition of $M$. indica peel or pulp. Phenolic compounds were commercially obtained (Sigma-Aldrich) and $0.1 \mathrm{M}$ stock solution of each one was prepared by dissolution in sterile distilled water. Solutions were shaken in orbital incubator at $30^{\circ} \mathrm{C}$ for one hour at $150 \mathrm{rpm}$ and later stored at $4^{\circ} \mathrm{C}$ until used. Solutions prepared with commercial phenolic compounds were added separately to chitosan.

\section{Preparation of filmogenic chitosan solutions}

For the preparation of chitosan solutions, methodology described by Bautista-Bãnos et al. (2003) with adaptations was adopted. Thus, $2.0 \mathrm{~g}$ of powder was dissolved in $100 \mathrm{~mL}$ of distilled water with $1 \%$ glacial acetic acid and left under constant stirring for 24 hours. Solutions were adjusted to $\mathrm{pH} 6.0$ by adding $1 \mathrm{~N} \mathrm{NaOH}$ and autoclaved at $121^{\circ} \mathrm{C}$ for 15 minutes to avoid any chitosan contamination.

In vitro evaluation of the fungicidal activity of chitosan associated with mango peel extracts or phenolic compounds

Aliquots of mango peel extract solutions and phenolic compounds were separately incorporated into the chitosan solution until final concentration of $2.0 \mathrm{mg}$ . $\mathrm{mL}^{-1}$ and $10 \mathrm{mM}$, respectively, was obtained. Therefore, the following treatments were used: chitosan + citric acid, chitosan + pyrocatecoic acid, chitosan + transcinamic acid, chitosan + gallic acid, chitosan + caffeine acid, chitosan + methyl gallate, chitosan + quercetin, chitosan + resorcinol, chitosan + methanolic extract, chitosan + hexanic extract and chitosan + ethyl acetate extract from mango peel. As controls, only culture medium (control) and culture medium incorporated with fungicide imazalil $\left(2 \mathrm{~mL} . \mathrm{L}^{-1}\right)$ were adopted. Treatments consisted of four replicates, one Petri dish per replicate.

For mycelial growth evaluation, chitosan solutions associated with extracts $\left(2.0 \mathrm{mg} . \mathrm{mL}^{-1}\right)$ or phenolic compounds $(10 \mathrm{mM})$ were added to Potato-Dextrose-Agar (PDA) culture medium and placed into $9 \mathrm{~cm}$ diameter Petri dishes. After culture medium solidification, a disk of $5 \mathrm{~mm}$ in diameter of $C$. tropicale mycelium with seven days of culture was transferred to the center of plates containing treatments. Then, Petri dishes were sealed with plastic film and incubated in BOD chamber at $25^{\circ} \mathrm{C}$ with 12 -h photoperiod. Evaluations were daily performed, measuring the mycelial growth diameter in two perpendicular directions using caliper graduated in millimeters. Measurements started 24 hours after the experiment was set up and ended when the control plate was completely taken up by the fungus.

After mycelial growth evaluation, $10 \mathrm{~mL}$ of sterile distilled water and a drop of Tween 80 were added to each plate. Using Drigalski loop, colonies were scraped to release spores. The spore suspension was filtered through a double layer of gauze and the solution volume was completed to $20 \mathrm{~mL}$. A drop of each suspension was placed in Neubauer chamber and with the aid of optical microscope, the number of produced conidia was counted.

The effect of chitosan associated with extracts or phenolic compounds on conidia germination was also verified. For this evaluation, chitosan solutions were added to $2 \%$ agar-water (AA) melting culture medium and placed into $9 \mathrm{~cm}$ diameter Petri dishes. After solidification with respective treatments, $150 \mu \mathrm{L}$ of conidia suspension at concentration of $2.5 \times 10^{5}$ spores. $\mathrm{mL}^{-1}$ of C. tropicale were spread over the surface of the culture medium. Plates were taken to BOD chamber at $25^{\circ} \mathrm{C}$ under $12-\mathrm{h}$ photoperiod. After 13 hours of incubation, the germination rate was determined by counting the germinated fungus conidia. One hundred conidia were evaluated under optical microscope, being considered germinated those that presented germ tube with length greater than or equal to the largest size of the conidium diameter.

Evaluation of anthracnose intensity in mango coated with chitosan and phenolic compounds

For the evaluation of the anthracnose intensity, mangoes cultivar 'Palmer' at physiological maturation stage 3 were used. In addition, the best treatments of the in vitro test were applied in this experiment.

After cleaning and drying, fruits were inoculated with $C$. tropicale by atomizing conidia suspension at concentration of $1.0 \times 10^{5}$ spores. $\mathrm{mL}^{-1}$ until reaching the point of runoff. Inoculated mangoes were submitted to humid chamber (RH 98\%) for 20 hours, and after this period, they were immersed for one minute in the following solutions: chitosan + pyrocatecoic acid, chitosan + citric acid, chitosan + transcinamic acid, chitosan + resorcinol. Fruits immersed in sterile water (control) and in fungicide imazalil $\left(2.0 \mathrm{~mL} . \mathrm{L}^{-1}\right)$ were used as controls. Fruits were left at room temperature to dry and then packed in expanded polystyrene trays. The statistical design was completely randomized with four treatments and four replicates, each replicate containing two fruits. 
Trays were randomly arranged on the bench, remaining for 15 days. The anthracnose intensity in fruits was evaluated by the incidence and severity every three days. Incidence was obtained by the number of symptomatic fruits per replicate, with values being expressed as percentage per treatment. Severity refers to the proportion of colonized tissue area, being determined with the aid of diagrammatic scale specific for anthracnose in mangoes (CORKIDI et al., 2006) with disease severity ranging from 0 to $1 \%$ (without disease); 1 to $5 \%$ (mild disease); 6 to $9 \%$ (moderate disease); 10 to $49 \%$ (severe disease), and 50 to $100 \%$ (very severe disease) of the injured/fruit area. Results were used to calculate the area under the disease progress curve (AUDPC) and the area under the disease severity curve (AUDSC) (SHANER; FINNEY, 1977).

\section{Statistical analysis}

Data were transformed into $\sqrt{ }(x+1)$ and submitted to analysis of variance. Means were compared by the Scott-Knott and Tukey test at 5\% probability, for in vitro tests and anthracnose intensity assessment, respectively. Controls were compared to the other treatments using the Dunnett test at 5\% probability. Analyses were performed using the statistical programs Sisvar (FERREIRA, 2008) and SAS (SAS, 2011).

\section{Results and Discussion}

In vitro evaluation of the fungicidal activity of chitosan associated with mango peel extracts or phenolic compounds

The use of chitosan with phenolic compounds and mango peel extracts was effective in controlling C. tropicale mycelial growth (Table 1) when compared with control, using the Dunnett test $(\mathrm{p}<0.05)$. Significant difference was observed between treatments by the ScottKnott test $(\mathrm{p}<0.05)$.

Table 1. Effect of the association of chitosan with phenolic compounds and extracts from mango peel 'Palmer' on the mean mycelial growth rate index (MGRI) of Colletotrichum tropicale

\begin{tabular}{lc}
\hline Treatment & MGRI $\left(\mathbf{m m . d a y} \mathbf{y}^{-1}\right)$ \\
\hline Chitosan + pyrocatecoic acid & $0.00 \mathrm{a} *$ \\
Chitosan + transcinamic acid & $0.00 \mathrm{a} *$ \\
Chitosan + citric acid & $0.00 \mathrm{a} *$ \\
Chitosan + resorcinol & $3.20 \mathrm{~b} * *$ \\
Chitosan + gallic acid & $3.54 \mathrm{~b} * * *$ \\
Chitosan + caffeic acid & $5.37 \mathrm{c} * * *$ \\
Chitosan + methanolic extract & $6.58 \mathrm{c} * *$ \\
Chitosan + hexanic extract & $8.13 \mathrm{~d} * * *$ \\
Chitosan + ethyl acetate extract & $8.70 \mathrm{~d} * * *$ \\
Chitosan + quercetin & $10.01 \mathrm{e} * * *$ \\
Chitosan + methyl gallate & $11.10 \mathrm{e} * * *$ \\
\hline Control & 31.40 \\
Imazalil & 0.00 \\
\hline CV $(\%)$ & $\mathbf{8 . 5 2}$ \\
\hline
\end{tabular}

Means followed by the same letter do not differ by the Scott-Knott test $(\mathrm{p}<0.05)$. Treatment averages followed by * and ** differ significantly from control and imazalil by the Dunnet test $(\mathrm{p}<0.05)$, respectively. 
Chitosan treatments associated with pyrocatecoic, transcinamic and citric acids proved to be as efficient as fungicide imazalil, as they showed $100 \%$ C. tropicale mycelial growth inhibition. Roy et al. (2018) reported inhibition in the mycelial growth of Colletotrichum acutatum, C. gloeosporioides, C. fragariae and $C$. graminicola with the application of transcinamic acid. However, the use of gallic acid, caffeic acid, quercetin and catechin at concentration of $50 \mathrm{mM}$, had no significant inhibitory effect on the growth of any of these isolates.

There are few reports of the possible inhibitory effects of chitosan associated with phenolic compounds on Colletotrichum species. However, there are some studies in literature that evaluated the effect of these compounds alone on other phytopathogens: transcinamic acid at concentrations of $10 \mathrm{mM}$ and $20 \mathrm{mM}$ was effective in inhibiting the growth of Aspergillus species (NESCI; ETCHEVERRY, 2006); Kim et al. (2004) observed limited antifungal activity of caffeic acid above $25 \mathrm{mM}$ for Aspergillus flavus, and the use of catechin and quercetin did not inhibit the in vitro development of Phlyctaena vagabonda (LATTANZIO et al., 2001).
In this study, chitosan treatments with hexanic and ethyl acetate extracts did not differ from each other by the Scott-Knott test $(p<0.05)$. Regarding control and imazalil, all treatments with extracts were different by the Dunnett test $(\mathrm{p}<0.05)$. Despite not completely inhibiting the pathogen growth, chitosan treatments with methanolic, hexanic and ethyl acetate extracts from mango peel provided lower mycelial growth compared to control. There was $79 \%$ reduction in mycelial growth with the application of chitosan + methanolic mango peel extract.

Silva et al. (2019) evaluated in vitro methanolic, hexane and ethyl acetate extracts from mango peel separately, without chitosan, and found no significant differences among them in the control of mycelial growth rate index (MGRI). However, synergistic effects on the inhibition of C. tropicale mycelial growth can be achieved when there is combined application of plant extracts or essential oils and chitosan (OLIVEIRA et al., 2018).

Total conidia production inhibition was observed with the application of chitosan + pyrocatecoic acid, chitosan + transcinamic acid, chitosan + citric acid and chitosan + resorcinol (Table 2). These filmogenic solutions, together with the treatment of chitosan + hexanic extract from mango peel, did not differ from fungicide imazalil, presenting results as satisfactory as this fungicide in the in vitro control of $C$. tropicale sporulation. Similar results were found when hexane extract from mango peel at concentration of $2 \mathrm{mg} . \mathrm{mL}^{-1}$ was separately applied on $C$. gloeosporioides (SILVA et al., 2019).

Table 2. Effect of the association of chitosan with phenolic compounds and extracts from mango peel 'Palmer' on the Colletotrichum tropicale conidia production

\begin{tabular}{lc}
\hline Treatment & Conidia production(spores. $\left.\mathbf{~} L^{-1}\right)$ \\
\hline Chitosan + pyrocatecoic acid & $0.00 \mathrm{a} *$ \\
Chitosan + transcinamic acid & $0.00 \mathrm{a} *$ \\
Chitosan + citric acid & $0.00 \mathrm{a} *$ \\
Chitosan + resorcinol & $0.00 \mathrm{a} *$ \\
Chitosan + hexanic extract & $0.50 \mathrm{a} *$ \\
Chitosan + gallic acid & $10.78 \mathrm{~b} * *$ \\
Chitosan + ethyl acetate extract & $11.22 \mathrm{~b} * *$ \\
Chitosan + caffeic acid & $14.09 \mathrm{~b} * * *$ \\
Chitosan + methanolic extract & $18.22 \mathrm{c} * *$ \\
Chitosan + quercetin & $25.94 \mathrm{~d} * *$ \\
Chitosan + methyl gallate & $35.87 \mathrm{e}^{* * *}$ \\
\hline Control & 22.06 \\
\hline Imazalil & 0.00 \\
\hline CV $(\%)$ & $\mathbf{1 0 . 1 4}$ \\
\hline
\end{tabular}

Means followed by the same letter do not differ by the Scott-Knott test $(\mathrm{p}<0.05)$. Treatment averages followed by * and ** differ significantly from control and imazalil by the Dunnet test $(\mathrm{p}<0.05)$, respectively. 
Conidia production in this experiment increased $62 \%$ in comparison with control when chitosan + methyl gallate was used (Table 2). Unlike the others, this treatment induced C. tropicale sporulation and is therefore not efficient for controlling spore production. The presence of phenolic compounds, organic and inorganic substances in extracts (AUDIBERT et al., 2010) can cause stress on microorganisms, thus stimulating the formation of infectious propagules. The knowledge of the effect of these products on fungal sporulation is of great relevance for the management of post-harvest diseases, since when disseminated, the spore has potential to cause diseases in healthy tissues.

For C. tropicale conidia germination (Table 3), all treatments presented behavior similar to fungicide in inhibiting germination, being, therefore, efficient for controlling this variable $(\mathrm{p}<0.05)$.

Table 3. Percentage of Colletotrichum tropicale conidia germination submitted to chitosan treatments with phenolic compounds and extracts from mango peel 'Palmer'

\begin{tabular}{ll}
\hline Treatment & Germination rate $\mathbf{( \% )}$ \\
\hline Chitosan + pyrocatecoic acid & $0.00 \mathrm{a} *$ \\
Chitosan + transcinamic acid & $0.00 \mathrm{a} *$ \\
Chitosan + citric acid & $0.00 \mathrm{a} *$ \\
Chitosan + resorcinol & $0.00 \mathrm{a} *$ \\
Chitosan + gallic acid & $0.00 \mathrm{a} *$ \\
Chitosan + quercetin & $0.00 \mathrm{a} *$ \\
Chitosan + methyl gallate & $0.00 \mathrm{a} *$ \\
Chitosan + methanolic extract & $0.00 \mathrm{a} *$ \\
Chitosan + hexanic extract & $0.00 \mathrm{a} *$ \\
Chitosan + ethyl acetate extract & $0.00 \mathrm{a} *$ \\
Chitosan + caffeic acid & $0.75 \mathrm{a} *$ \\
\hline Control & 81.5 \\
\hline Imazalil & 0.00 \\
\hline CV $(\%)$ & $\mathbf{1 4 . 1 4}$ \\
\hline
\end{tabular}

Means followed by the same letter do not differ by the Scott-Knott test $(\mathrm{p}<0.05)$. Treatment averages followed by * and ** differ significantly from control and imazalil by the Dunnet test $(p<0.05)$, respectively.

Albíter-Hernández et al. (2007) found reduction in the percentage of conidia germination (7\%) for one of $C$. gloeosporioides isolates using crude extract from mango leaves. The germination of $C$. gloeosporiodes spores was even more sensitive than mycelial growth when $2.0 \%$ chitosan was applied (JITAREERAT et al., 2007). Chitosan was not able to inhibit the germination of $C$. gloeosporioides conidia when applied alone (COQUEIRO et al., 2018) in contrast to the use of salicylic acid, demonstrating that the combined use of chitosan with other organic molecules can improve its antifungal properties.

The development of biodegradable films combined with plant extracts appears as one of the most interesting strategies in the near future. Polymers incorporated with extracts from plant by-products such as mango peel (ADILAH et al., 2018) and leaves (RAMBABU et al., 2019) and other bioactive substances received greater attention because they contain high concentrations of phenolic compounds and components with high antioxidant activity (MIR et al., 2018), resulting in improvements in physical, chemical and antimicrobial properties compared to films made from individual components.

The present study demonstrated that the association of chitosan with phenolic compounds and hexanic, methanolic and ethyl acetate extracts from mango peel is effective in controlling in vitro $C$. tropicale development. These data enable directing research into the alternative management of mango anthracnose with the use of less toxic products, with a view to replacing the use of fungicides.

\section{Evaluation of anthracnose intensity in mango coated with chitosan and phenolic compounds}

According to data presented in Table 4 for the area under the disease progress (AUDPC) and severity (AUDSC) Curves, no significant differences were found among treatments $(p<0.05)$. However, when the Dunnet test was applied, it was observed that all treatments differed from both control and imazalil. 
Table 4. Area under the disease progress (AUDPC) and severity (AUDSC) curves of mango anthracnose (Mangifera indica) inoculated with Colletotrichum tropicale and submitted to chitosan treatments with phenolic compounds

\begin{tabular}{lll}
\hline Treatment & AUDPC & AUDSC \\
\hline Chitosan + pyrocatecoic acid & $0.00 \mathrm{a}^{* * *}$ & $0.00 \mathrm{a} * * *$ \\
Chitosan + resorcinol & $131.25 \mathrm{a} * * *$ & $2.06 \mathrm{a} * * *$ \\
Chitosan + transcinamic acid & $187.50 \mathrm{a} * * *$ & $2.62 \mathrm{a} * * *$ \\
Chitosan + citric acid & $337.50 \mathrm{a} * * *$ & $6.00 \mathrm{a} * * *$ \\
\hline Control & 862.50 & 222.56 \\
\hline Imazalil & 787.50 & 148.5 \\
\hline CV (\%) & $\mathbf{4 2 . 3 9}$ & $\mathbf{4 2 . 5 4}$
\end{tabular}

Means followed by the same letter do not differ from each other by the Tukey test $(\mathrm{p}<0.05)$. Treatment averages followed by $*$ and $* *$ differ significantly from control and imazalil by the Dunnet test $(\mathrm{p}<0.05)$, respectively.

Phenolic acids associated with chitosan were able to reduce anthracnose incidence and severity in mango, showing better results compared to imazalil in controlling the disease. Results similar to those of this work were described by Oliveira et al. (2018), in which chitosan coating with Cymbopogon citratus essential oil provided low anthracnose severity in mangoes inoculated with C. tropicale when compared with synthetic fungicides thiophanate-methyl and diphenoconazole.

Antifungal resorcinol was isolated and identified in mango peel and suggested as the cause of resistance of the green fruit to attack by C. gloeosporioides (DROBY et al., 1986; KARUNANAYAKE et al., 2011). The results of this work suggest that other phenolic compounds may also be associated with the control of anthracnose in mango.

Increase in antifungal activity through additive effects or synergistic interactions in chitosan films combined with other substances can be achieved by the fact that this polymer disturbs the permeability of fungal membranes and reduces the synthesis of cell wall components (OLIVEIRA et al., 2017). Consequently, there may be a decrease in the ability of fungi to tolerate the effects of incorporated substances (ELSABEE; ABDOU, 2013). The stress caused by chitosan can increase the partition of constituents of plant extracts and phenolic compounds in fungal cells, causing them to act on target structures. The incorporation of bioactive components in films is proposed to be more effective in extending the shelf life of fruits compared to the individual application, as these components are continuously released over time on the fruit surface, maintaining adequate concentration during storage (OLIVEIRA et al., 2017).

Several different phenolic compounds have been individually incorporated into chitosan films (LIU et al., 2017) and have been reported as excellent coatings for fruits, as these substances improve the physical and chemical characteristics, in addition to the functionalities and antioxidant power of chitosan. This work demonstrates that other compounds such as pyrocatecoic acid, transcinamic acid and citric acid, in addition to resorcinol, are involved in the control of anthracnose in mango.

\section{Conclusion}

The association of chitosan with phenolic compounds and plant extracts has in vitro antifungal potential. The incorporation of pyrocatechoic acid, transcinamic acid, citric acid and resorcinol in chitosan solutions significantly reduces the incidence and severity of mango anthracnose caused by $C$. tropicale.

\section{Acknowledgments}

The authors would like to thank the financial support from CAPES, CNPq and FAPEMIG.

\section{References}

ADIKARAM, N.K.B.; KARUNANAYAKE, L.C.; SINNIAH, G.D.; ABAYASEKARA, C.L.; KOMALA, V.S.; YAKANDAWALA, D.M.D. A review of the role for natural defences in the management of Colletotrichum rotting of ripe mangoes. Acta Horticulturae, The Hague, v.1183, p.229-232, 2015.

ADILAH, A.N.; JAMILAH, B.; NORANIZAN, M.A.; HANANI, Z.N. Utilization of mango peel extracts on the biodegradable films for active packaging. Food Packaging and Shelf Life, Amsterdam, v.16, p.1-7, 2018.

AGATONOVIC-KUSTRIN, S.; KUSTRIN, E.; MORTON, D.W. Phenolic acids contribution to antioxidant activities and comparative assessment of phenolic content in mango pulp and peel. South African Journal of Botany, Amsterdam, v.116, p.158-163, 2018. 
A GROFIT. Sistemas de agrotóxicos fitossanitários. Brasília: Ministério da Agricultura, Pecuária e Abastecimento, 2019. Disponível em: http:// agrofit.agricultura.gov.br/agrofit_cons/principal_agrofit cons. Acesso em: 01 ago. 2019.

AJILA, C.M.; NAIDU, K.A.; BHAT, S.G.; RAO, U.P. Bioactive compounds and antioxidant potential of mango peel extract. Food Chemistry, London, v.105, n.3, p. 982-988, 2007.

ALBÍTER- HERNÁNDEZ, R.C.; BARRERA-NECHA, L.L.; BAUTISTA-BAÑOS, S.; BRAVO-LUNA, L. Antifungal Potential of Crude Plant Extracts on Conidial Germination of Two Isolates of Colletotrichum gloeosporioides (Penz.) Penz. and Sacc. Revista Mexicana de Fitopatología, Chapingo, v.25, n.2, p.180$185,2007$.

ALJAWISH，A.; MUNIGLIA， L.; KLOUJ, A.; JASNIEWSKI, J.; SCHER, J.; DESOBRY, S. Characterization of films based on enzymatically modified chitosan derivatives with phenol compounds. Food Hydrocolloids, Oxford, v.60, p.551-558, 2016.

ALOUI, H.; KHWALDIA, K.; LICCIARDELLO, F.; MAZZAGLIA, A.; MURATORE, G.; HAMDI, M.; RESTUCCIA, C. Efficacy of the combined application of chitosan and Locust Bean Gum with different citrus essential oils to control postharvest spoilage caused by Aspergillus flavus in dates. International Journal of Food Microbiology, Amsterdam, v.170, p.21-28, 2014.

ATARÉS, L.; CHIRALT, A. Essential oils as additives in biodegradable films and coatings for active food packaging. Trends in Food Science \& Technology, Cambridge, v.48, p.51-62, 2016.

AUDIBERT, L.; FAUCHON, M.; BLANC, N.; HAUCHARD, D; AR GALL, E. Phenolic compounds in the brown seaweed Ascophyllum nodosum: distribution and radical scavenging activities. Phytochemical Analysis, New York, v.21, n.5, p.399-405, 2010.

BATISTA, D.D.C.; RIBEIRO JUNIOR, P.M.; BARBOSA, M.; ANDRADE, J.N.; TERAO, D. Doenças da mangueira. Informe Agropecuário, Belo Horizonte, v.37, n.290, p. 82-91, 2016.
BAUTISTA-BAÑOS, S.; HERNÁNDEZ-LÓPEZ, M.; BOSQUEZ-MOLINA, E.; WILSON, C.L. Effects of chitosan and plant extracts on growth of Colletotrichum gloeosporioides, anthracnose levels and quality of papaya fruit. Crop Protection, Oxford, v.22, n.9, p.1087-1092, 2003.

BAUTISTA-BAÑOS, S.; ROMANAZZI, G.; JIMÉNEZAPARICIO, A. Chitosan in the preservation of agricultural commodities. Oxford: Academic Press, 2016. 384 p.

BRITO, C.H.; LOPES, E.B.; ALBUQUERQUE, I.C.; BATISTA, J.L.; SILVA, A B. Uso do tratamento térmico no controle de mosca-das-frutas (Ceratitis capitata). Tecnologia e Ciência Agropecuária, Porto Alegre, v.3, p.29-36, 2009.

CHOI, C.; NAM, J.P.; NAH, J.W. Application of chitosan and chitosan derivatives as biomaterials. Journal of Industrial and Engineering Chemistry, Columbus, v.33, p.1-10, 2016.

COQUEIRO, D.S.O.; PEDREIRA, D.P.; SILVA, R.P. da; De SOUZA, A.V.L.; SANTOS, A. In vitro development of Colletotrichum gloeosporioides (Penz.) Penz. \& Sacc. isolated from coffee in the presence of chitosan and salicylic acid. Magistra, Cruz das Almas, v.29, p.335$345,2018$.

CORKIDI, G.; BALDERAS-RUÍZ, K. A.; TABOADA, B.; SERRANO-CARREÓN, L.; GALINDO, E. Assessing mango anthracnose using a new three-dimensional imageanalysis technique to quantify lesions on fruit. Plant Pathology, Oxford, v.55, n.2, p.250-257, 2006.

DROBY, S.; PRUSKY, D.; JACOB, B.; GOLDMAN, A. Presence of antifungal compounds in the peel of mango fruits and their relation to latent infection of Alternaria alternata. Physiological and Molecular Plant Pathology, London, v.9, n.2, p.173-183, 1986.

EL HADRAMI, A.; EL HADRAMI, I.; DAAYF, F. Suppression of induced plant defense responses by fungal pathogens. Molecular-Plant Microbe Interactions, Saint Paul, v.10, p.231-268, 2010.

ELSABEE, M.Z.; ABDOU, E.S. Chitosan based edible films and coatings: A review. Materials Science and Engineering, Amsterdam, v.33, n.4, p.1819-1841, 2013. 
ESHETU, A.; IBRAHIM, A.M.; FORSIDO, S.F.; KUYU, C.G. Effect of beeswax and chitosan treatments on quality and shelf life of selected mango (Mangifera indica L.) cultivars. Heliyon, London, v.5, p.1116, 2019.

FERREIRA, D.F. SISVAR: Um programa para análises e ensino de estatística. Revista Symposium, Lavras, v.6, p.36-41, 2008.

GALUS, S.; KADZINSKA, J. Food applications of emulsion-based edible films and coatings. Trends in Food Science \& Technology, Cambridge, v.45, n.2, p.273-283, 2015.

HAMED, I.; OZOGUL, F.; REGENSTEIN, J. M. Industrial applications of crustacean by-products (chitin, chitosan and chitooligosaccharides): A review. Trends in Food Science \&Technology, Cambridge, v.48, p.40-50, 2016.

JITAREERAT, P.; PAUMCHAI, S.; KANLAYANARAT, S.; SANGCHOTE, S. Effect of chitosan on ripening, enzymatic activity, and disease development in mango (Mangifera indica) fruit. New Zealand Journal of Crop and Horticultural Science, Wellington, v.35, p.211-218, 2007.

KARUNANAYAKE，L.C.; ADIKARAM，N.; KUMARIHAMY, B.M.M.; BANDARA, B.M.R.; ABAYASEKARA, C. Role of antifungal gallotannins, resorcinols and chitinases in the constitutive defence of immature mango (Mangifera indica L.) against Colletotrichum gloeosporioides. Journal of Phytopathology, Berlin, v.159, n.10, p.657-664, 2011.

KIM, H.; MOON, J.Y.; KIM, H.; LEE, D.S.; CHO, M.; CHOIM, H.K.; CHO, S.K. Antioxidant and antiproliferative activities of mango (Mangifera indica L.) flesh and peel. Food Chemistry, London, v.121, n.2, p.429-436, 2010.

KIM, J.H.; CAMPBELL, B.C.; MAHONEY, N.E.; CHAN, K.L.; MOLYNEUX, R.J. Identification of phenolics for control of Aspergillus flavus using Saccharomyces cerevisiae in a model target-gene bioassay. Journal of Agricultural and Food Chemistry, Washington, v.52, n.26, p.7814 -7821, 2004.
LATTANZIO, V.; DI VENERE, D.; LINSALATA, V.; BERTOLINI, P.; IPPOLITO, A.; SALERNO, M. Low temperature metabolism of apple phenolics and quiescence of Phlyctaena vagabonda. Journal of Agricultural and Food Chemistry, Washington, v.49, n.12, p.5817-5821, 2001.

LIMA, N.B.; BATISTA, M.V.D.A.; MORAIS, M.A.; BARBOSA, M.A.; MICHEREFF, S.J.; HYDE, K.D.; CÂMARA, M.P. Five Colletotrichum species are responsible for mango anthracnose in northeastern Brazil. Fungal Diversity, Hong Kong, v.61, p.75-88, 2013.

LIMA, N.B.; LIMA, W.G.; TOVAR-PEDRAZA, J.M.; MICHEREFF, S.J.; CÂMARA, M.P.S. Comparative epidemiology of Colletotrichum species from mango in northeastern Brazil. European Journal of Plant Pathology, Dordrecht, v.141, p.679-688, 2015.

LIU, J.; LIU, S.; WU, Q.; GU, Y.; KAN, J.; JIN, C. Effect of protocatechuic acid incorporation on the physical, mechanical, structural and antioxidant properties of chitosan film. Food Hydrocolloids, Oxford, v.73, p.90100, 2017.

MALERBA, M.; CERANA, R. Chitosan effects on plant systems. International Journal of Molecular Sciences, Basel, v.17, n.7, 996, 2016.

MIR, S. A.; DAR, B. N.; WANI, A. A.; SHAH, M. A. Effect of plant extracts on the techno-functional properties of biodegradable packaging films. Trends in Food Science \& Technology, Cambridge, v.80, p.141-154, 2018.

MOUCO, M.A.C. (ed.). Cultivo da mangueira. 2.ed. Petrolina: Embrapa Semiárido, 2010. Disponível em: https://www.infoteca.cnptia.embrapa.br/bitstream/ doc/884451/1/CultivodaMangueira.pdf. Acesso em: 20 jan. 2019.

NEGREIROS, R.D.; SALOMÃO, L.C.C.; PEREIRA, O.L.; CECON, P.R.; SIQUEIRA, D.D. Controle da antracnose na pós-colheita de bananas-prata com produtos alternativos aos agrotóxicos convencionais. Revista Brasileira de Fruticultura, Jaboticabal, v.35, n.1, p.5158, 2013. 
NESCI, A.V.; ETCHEVERRY, M.G. Control of Aspergillus growth and aflatoxin production using natural maize phytochemicals under different conditions of water activity. Pest Management Science, London, v.62, n.8, p. 775-784, 2006.

NTSOANE, M.L.; ZUDE-SASSE, M.; MAHAJAN, P.; SIVAKUMAR, D. Quality assesment and postharvest technology of mango: A review of its current status and future perspectives. Scientia Horticulturae, New York, v.249, p.77-85, 2019.

OLIVEIRA, K.A.R.; BERGER, L.R.R.; ARAÚJO, A.S. de; CÂMARA, M.P.S.; SOUZA, E.L. de. Synergistic mixtures of chitosan and Mentha piperita L. essential oil to inhibit Colletotrichum species and anthracnose development in mango cultivar Tommy Atkins. Food Microbiology, United Kingdom, v.66, p.96-103, 2017.

OLIVEIRA, P. D. L.; De OLIVEIRA, K. A. R.; VIEIRA, W. A. S., CÂMARA, M. P. S.; De SOUZA, E. L. Control of anthracnose caused by Colletotrichum species in guava, mango and papaya using synergistic combinations of chitosan and Cymbopogon citratus (DC ex Nees) Stapf. essential oil. International Journal of Food Microbiology, Netherlands, v.266, p.87-94, 2018.

RAMBABU, K.; BHARATH, G.; BANAT, F.; SHOW, P. L.; COCOLETZI, H. H. Mango leaf extract incorporated chitosan antioxidant film for active food packaging. International Journal of Biological Macromolecules, United Kingdom, v.126, p.1234-1243, 2019.

ROY, S.; NUCKLES, E.; ARCHBOLD, D. D. Effects of phenolic compounds on growth of Colletotrichum spp. in vitro. Current Microbiology, United States, v.75, p.550$556,2018$.

RUBILAR, J. F.; CRUZ, R. M.; SILVA, H. D.; VICENTE, A. A.; KHMELINSKII, I.; VIEIRA, M. C. Physicomechanical properties of chitosan films with carvacrol and grape seed extract. Journal of Food Engineering, New York, v.115, n.4, p.466-474, 2013.
SANTOS, N. S. T.; AGUIAR, A. J. A. A.; OLIVEIRA, C. E. V.; SALES, C. V.; SILVA, S. D. M.; SILVA, R. S.; SOUZA, E. L. Efficacy of the application of a coating composed of chitosan and Origanum vulgare L. essential oil to control Rhizopus stolonifer and Aspergillus niger in grapes (Vitis labrusca L.). Food Microbiology, London, v.32, n.2, p.345-353, 2012.

SAS. SAS/STAT 9.3 user's guide. Cary, 2011. 8621 p.

SHANER, G.; FINNEY, R.E. The effect of nitrogen fertilization on the expression of slow mildewing resistance in Knox wheat. Phytopathology, Saint Paul, v.67, p.1051-1056, 1977.

SILVA, L.S.; MIZOBUTSI, E.H.; MIZOBUTSI, G.P.; De OLIVEIRA, D.F.; CAMPOS, V.A.C.; MONÇÃO, F.P.; RIBEIRO, R.C.F.; CÂMARA, M.P.S.; RODRIGUES, M.L.M. Evaluation of mango peel extracts on the in vitro Colletotrichum gloeosporioides development. Journal of Experimental Agriculture International, Gurgaon, v.32, n.6, p.1-8, 2019.

SIRIPATRAWAN, U.; VITCHAYAKITTI, W. Improving functional properties of chitosan films as active food packaging by incorporating with propolis. Food Hydrocolloids, Oxford, v.61, p.695-702, 2016.

VAN DEN BROEK, L.A.; KNOOP, R.J.; KAPPEN, F.H.; BOERIU, C.G. Chitosan films and blends for packaging material. Carbohydrate Polymers, Amsterdam, v.116, p.237-242, 2015.

WU, C.; TIAN, J.; LI, S.; WU, T.; HU, Y.; CHEN, S. Structural properties of films and rheology of filmforming solutions of chitosan gallate for food packaging. Carbohydrate Polymers, Amsterdam, v.116, p.10-19, 2016.

ZHENG, M.; SHI, J.; SHI, J.; WANG, Q.; LI, Y. Antimicrobial effects of volatiles produced by two antagonistic Bacillus strains on the anthracnose pathogen in postharvest mangos. Biological Control, Dordrecht, v.65, n.2, p.200-206, 2013. 